\title{
Inclusive education in the academy: Pedagogical and political imperatives in a master's course
}

\begin{abstract}
Many universities offer undergraduate and postgraduate courses in inclusive education. There has been much research into the impact of these courses, but little is written about their design. This article focuses on a master's course in inclusive education in a South African university. The course positions inclusive education as a critical education project and is designed around the four propositions presented by Slee in The Irregular School (2011. Milton Park: Routledge). Using Bernsteinian ideas about pedagogising knowledge, this article accounts for the pedagogical choices made in content selection and course design. The focal questions in the course are described, together with an indication of the range of additional texts that students read. Given that Slee asserts that inclusive education is a political project, and that Allan (2010. "The Inclusive Teacher Educator: Spaces for Civic Engagement." Discourse: Studies in the Cultural Politics of Education 31 (4): 411-422) urges inclusive teacher educators to reorientate themselves towards civic duty, I argue that producing a pedagogic discourse of inclusive education is a political task that should result in both the teacher educator and the students being oriented towards a critique of existing exclusionary arrangements and an activism that leads to change.
\end{abstract}

\section{Keywords}

Inclusive education; teacher education for inclusive education; pedagogising knowledge; critical education

\section{Introduction}

Over the past three decades, the idea of inclusive education has become well established in the academic and policy domains. It has been variously dismissed as a meaningless buzzword or as an unworkable ideal, or lauded as an insurrectionary idea that challenges the foundations of an inherently exclusionary education system. Among its many iterations, inclusive education has become a field of study, and many universities now offer courses, programmes or qualifications in its name. It is, however, a field without a clear theoretical foundation (Allan, 2010; Armstrong, Armstrong, and Spandagou, 2011). Various disciplines, theories, fields and discourses can be considered as "clusters of influence" (Slee 2011, 63) which have contributed to what is known as inclusive education. This lack of a clear disciplinary base makes for an expansive, contested and very fluid field of knowledge 
production from which teacher educators can develop curricula. As a result, the content of what is taught as inclusive education varies significantly across institutions, with very different ideas about what counts as legitimate knowledge of, for and about inclusive education (Walton, 2017). Inclusive education in the academy has been rightly criticised with Allan $(2010,411)$ raising a concern that the obligations arising within Higher Education “...contribute to a loss of civic engagement and a lack of capacity to pursue inclusion, social justice and equity". Despite critique, courses in inclusive education have been feted as the catalyst for the attitude change that teachers of diverse learners are said to need (Sharma, Forlin, and Loreman, 2008). In this article I contribute to the conversation about teaching inclusive education in higher education by critically reflecting on the design of a masters course.

This article commences with a discussion of teacher education for inclusive education with a focus on content selection in inclusive education courses through a Bernsteinian lens. In so doing, I address Waitoller and Artiles's (2013) concern that teacher education for inclusive education is undertheorised. After an explanation of the course in the South African context, I present each of Slee's propositions, describe it briefly, and then discuss the questions it prompted and how these were given substance through selected texts and learning activities. In this discussion, I refer to Allan's (2010) article “The inclusive teacher educator: Spaces for civic engagement". Here, Allan draws attention to pressures on contemporary academics and the pitfalls that those concerned with issues of social justice and inclusivity in education might encounter. She argues for inclusive teacher educators to reclaim and re-inhabit the political dimension of their work. In a course crafted around Slee's (2011) book, The irregular school, which explicitly positions inclusive education as a "political project" (2011, 84), Allan's comments are taken up. I conclude by arguing that part of the political work that inclusive teacher educators must do is to produce a pedagogic discourse of inclusive education that challenges injustice and exclusion in education.

\section{Inclusive education in the academy}

The international trend of promoting education that is more inclusive of diverse learners has been accompanied by the growth of courses in inclusive education in undergraduate and postgraduate programmes. This growth has been fuelled by the oft-repeated lament of teacher un(der)preparedness for teaching inclusively in classes that represent learners with different educational needs, particularly when those needs are deemed to be 'special'. There is 
burgeoning research interest in teacher education for inclusive education, as scholars seek to understand what form and content of inclusive education courses leads to the knowledge, skills and attitudes (Rouse, 2010) required for more inclusive teaching, and what possible impact these courses have on learners and learning (Florian, 2012). I argue here that this scholarship needs to go further in problematising the knowledge of inclusive education as it is presented in university courses.

The conceptual frameworks of Basil Bernstein are useful in understanding knowledge in curriculum and pedagogy in the context of higher education (Coleman, 2012). Knowledge, according to Bernstein (2000), is 'pedagogised' as teacher educators and textbook writers (called 'recontextualising agents') select knowledge from the field of specialist knowledge production and render it in a form (usually curricula and texts) that is accessible to nonspecialists. Recontextualisation is summed up by Coleman $(2012,328)$ as the process whereby "knowledge produced outside the curriculum is selectively appropriated and transformed into teachable material within the curriculum". Within this framework, the field of inclusive education can be scrutinised in terms of how the knowledge it produces comes to be recontextualised to construct particular pedagogic (or instructional) discourses. This process, maintains Singh $(2002,575)$ has implications for

'what' knowledge is available to be converted into pedagogic communication, 'who' ... will undertake the work of pedagogising knowledge, and 'how' this knowledge is transformed into pedagogic forms.

To consider 'what' inclusive education knowledge is available for conversion into pedagogic communication, it is helpful to understand the type of knowledge that 'inclusive education' is, because the type of knowledge will influence selection decisions made in the recontextualising process. For Bernstein, hierarchical and horizontal knowledge structures can be identified. The sciences are characterised by hierarchical knowledge structures, in that they develop "general propositions and theories which integrate knowledge at low levels" which show underlying uniformities (Bernstein, 2000, 161). By contrast, horizontal knowledge structures consist of the serial accumulation of competing theoretical paradigms or 'languages'. Knowledge in inclusive education could, with some caution, be regarded as a horizontal knowledge structure in that it comprises an array of "languages", rather than "any one exemplary theory" (Bernstein, 2000, 165) and these languages "make different and often opposing assumptions" (p. 162). The horizontality of the knowledge of inclusive education means that the recontextualising process will entail the privileging of one or more discourses, 
approaches or 'languages' over the others. The field of inclusive education is replete with an array of competing and complementing 'languages', which could and do find themselves privileged in university courses. These may include special education, with reference to medicine and psychology; critical theories, including disability theories; curriculum, pedagogy and assessment; and the 'needs' and characteristics of groups constituted by identity marker (Slee, 2011).

Given these competing 'languages' in the field of inclusive education, the grounds on which selection and privileging of knowledge in courses needs to be made more explicit. Bernstein (2000) has noted that the process of recontextualisation is invisible to those who must acquire the knowledge. As a result, students are not likely to be aware of the processes and perspectives that generate and legitimate the pedagogic discourses of inclusive education that they encounter. I would suggest that this invisibility might equally apply to the community of researchers in inclusive education where the content of inclusive education courses is often taken as given, without explicit account of how and why certain topics come to be privileged for selection. Where studies show the impact of courses in inclusive education on the attitudes enrolled students, there is seldom any critical interrogation of the processes whereby these courses are constituted and the ideological positions that inform content selection and delivery. In the light of this gap, this article focuses on the pedagogical choices made in the design and development of a particular course, rather than students' perceptions of the value or impact of the course. In so doing, I follow Luckett (2009) in exploring the teacher educator as an agent of recontextualisation, rather than students as agents of learning.

\section{Producing a pedagogic discourse of inclusive education}

The recontextualising process involves the selective appropriation, relocation, refocusing and relating of other discourses to produce the pedagogic discourse (Bernstein, 2000, 33). In the case of inclusive education, teacher educators must find coherent and principled grounds on which to select and organise knowledge from the field of knowledge production to enable systematic learning (Morrow, 2007) and to offer post-graduate students a legitimate 'gaze' (Bernstein, 2000) on the field. Ideological positions (and struggles) will certainly play a role here (Bernstein, 2000), as teacher educators come to inclusive education from various disciplinary and metatheoretical backgrounds. Producing a pedagogic discourse of inclusive 
education is thus a "subjective practice ... informed by social interests and relations" (Luckett, 2009, 442).

Content selection for this course positions inclusive education primarily as an issue of schools as societies, within a critical theoretical tradition. There are alternative positions that could be considered in the recontextualision process, reflecting some of the other influences (Slee, 2011) on the field. These include positioning inclusive education as an issue of students and their diversity, within special education, medical, psychological or sociological traditions; or as an issue of teachers and teaching, with a focus on curriculum, pedagogy and assessment in an inclusive classroom (Walton and Rusznyak, 2017). Good arguments may be made for these and other alternative positions, and many successful masters programmes around the world reflect these positions either on their own or in combination. The limited time and scope of any masters course necessitates both content selection and rejection. In the course described in this article, there is relatively little content that deals with specific diversity markers, nor with pedagogical practices. These issues are addressed in other courses in the masters programme, enabling this course to focus on inclusion in schools as a precondition for democracy (Bernstein, 2000; Slee, 2011)

There are also many possible organising principles that could inform the structure of a course in inclusive education. Basing a course on a prescribed text offers one way to secure logical coherence and systematic learning. Textbooks offer "context-sensitive and systematic explorations of subject-matter within coherent conceptual frameworks" (Morrow, 2007, 65) in contrast to course reading packs which are compiled from what Shalem and Slonimsky $(2010,21)$ call "bits and pieces selected from different contexts and genres of text". There is no dearth of textbooks written for students studying inclusive education, and there has been useful scholarly comment on the affordances and limitations of these books (see, for example, Black-Hawkins (2012), Brantlinger (2006); Rice (2005) and Walton (2016)).

In the masters course under discussion, I have chosen to expose students to a scholarly text as a component of their academic development. I regard it as valuable that students engage with the ideas and theories of an author or authors as systematically presented in a volume published for a scholarly (as opposed to specifically student) readership. The sustained engagement with the development and substantiation of an argument in a well-written book serves as a counterpoint to the potentially atomistic nature of the content of compiled course 
reading packs, and to the vagaries of the "political, economic, and cultural activities, battles and compromises" (Apple and Christian-Smith, 1991, 1) that characterise textbook production. This does not imply that the selection and privileging of scholarly books for postgraduate students is unproblematic_ “ "ideological screens" (Bernstein, 2000, 115) will come into play and will influence which books and authors are selected, and for what purpose. Brantlinger $(2006,50)$, for example, confesses to prescribing a book on the grounds that it was "... unusual, interesting, informative, and had a new take on special education".

My decision to prescribe The irregular school was based on a number of reasons to do with the qualities of book itself, the goals of masters studies in South Africa, and my ideological commitment to critical education that produces scholarly activism. First, the book has been well reviewed as making a "forward-thinking contribution to theory and discourse surrounding the idea of how to best educate all children" (Loreman, 2013, 440). As such, I expect the book to be thought provoking and to introduce post-graduate students to ideas and ways of thinking that might be unfamiliar to them. In her review of this book, Yates (2012, 441) notes that Slee uses a variety of "big name theorists", creating dialogue "with a huge raft of his fellow education researchers". This is potentially useful in the pedagogical task of introducing students to the "canonical names" (Bernstein, 2000, 164) in the field.

The second reason for prescribing this text is derived from the purpose of a masters degree in South African education, which is "to prepare researchers who could contribute to the development of knowledge in the field of Education" (Republic of South Africa, 2015, 45). Because the masters degree is not a professional qualification, it is not intended to lead to improved practice (although it should do, as teachers come to think more deeply about their practice as a result of the theories and concepts that they encounter). This means that the course is, in Bourdieu's terms "outside the urgency of a practical situation" (cited in Allan, 2010, 415). In terms of inclusive education, a masters course in this context is not designed to prepare students for inclusive teaching or for the learners they may encounter in an inclusive classroom. Instead, it is intended to contribute to what Morrow $(2007,49)$ calls the "arduous route" to acquiring academic discipline.

A final reason for prescribing this text is its potential to stimulate the kind of critical reflection that might result in activism for change. In The irregular school, Slee $(2011,155)$ positions inclusive education as a 'subset of critical education', saying that it ... 
... asks questions about the power relations of schooling, bears witness to injustice and seeks an educational settlement that will provide the knowledge, skills and dispositions necessary for a better world.

The choice of this book as a prescribed text means that various critical traditions (like critical literacy and critical disability studies) are foregrounded. This makes it possible to select topics and additional texts that that expose the workings of power and critique taken-forgranted assumptions and practices. The demand inherent in a critical approach to education is not only to reveal the power at work in sustaining injustice and oppression, but also to set an agenda for change. The initial call for critique may be sufficient for an armchair academic, but re-imaging (cf. Bernstein, 2000) schools is no small task. Each of Slee's four propositions is associated with an "agenda of tasks ... [which] carry the propositions ... through to activism" (2011, 153). This reflects what Allan calls the "civic duty" (Allan, 2010, 415) of the inclusive teacher educator which includes embracing inclusion as an ethical project and the removal of exclusionary practices on behalf of others.

\section{Students and structure}

The course under discussion is one that comprises one third of the coursework requirements of a Master of Education degree in a South African university. The course forms part of a suite of courses that are concerned with issues relevant to social justice, equity, diversity and inclusion in education. Students who enrol in this programme are mostly practising teachers, studying part-time. Most are South African, but each year the class includes students from neighbouring countries. The course lasts a semester, which is 12 or 13 weeks long, and students attend one two-hour contact session per week and are expected to do three to four hours of reading and writing in preparation for each session.

Students in this masters course must not only read The irregular school, but also at least two additional papers (journal articles or chapters) in preparation for their classes. A set of questions requiring a written response is given to guide and support the students in their reading and help them identify salient points. This is an intentional pedagogical decision made to facilitate students' access to the academic texts, and which I do explicitly to model ways of supporting access to learning. Course preparation also requires a written 'reflection task' each week. This task is informed by Allan's $(2005,293)$ statement that inclusion is not "something we do to a discrete population of children, but rather ... something that we must do to ourselves". A series of questions prompt students to reflect critically on their own 
stance and experience in relation to the ideas emerging in the readings. The overall focus of each session is framed by a question, rather than a topic. This is done deliberately to,

... Refuse some of the closure in thinking that surrounds inclusion and education more generally ... [and] to begin to do justice (in both senses) to the complexity and messiness of the processes of inclusion and exclusion (Allan, 2010, 416).

\section{Using Slee's propositions for course design}

In the section that follows, I briefly show how each of Slee's propositions serves as a prompt for the selection of knowledge and its recontextualisation into a curriculum for the course. In acknowledging my role as a recontextualising agent, I account for the selection of texts and how I have used them to further the critical education project that I espouse. Slee does not suggest that the propositions have any priority in terms of their urgency, but for ease of access, the course follows the order in which they are presented in The irregular school.

\section{Proposition one: Re-framing the field}

The first proposition is that "Inclusive education declares its commitment to identifying and dismantling educational exclusion" (Slee, 2011, 153). In explaining this proposition, Slee expresses a concern with the way that inclusive education has become domesticated, as attempts have been made to integrate the idea of inclusive education into existing special education discourses. The status quo remains; as inclusive education is reduced to a palatable rendition of what, in fact, is an insurrectionary idea. Slee thus argues for the decoupling of inclusive education from special education. Taking this up in coursework is no easy endeavour, at least not in the South African context. Many students come to the course with the supposition that inclusive education and special education are allied, if not synonymous. It is a surprise to some students that the course does not commence with special education, but with "the recognition of the unequal social relations that produce exclusion" (Slee, 2011, 39).

The framing question of the first session is very broad, and asks What is educational exclusion? Students are invited to consider the exclusionary pressures and practices and the unequal power relations that result in some learners occupying precarious positions as tenants on the margins of schools and schooling (Slee, 2011, 107). Or, as Slee (2000, 3) previously urged, an "interrogation of the way in which schooling excludes some children while sponsoring others". This is seen against the reality that although South Africa has achieved near universal school enrolment in terms of the Millennial Goals, at least 200000 South African children and young people not in 
schools. The government attributes this, in part, to the unmet 'special needs' that these children and young people experience (Department of Basic Education, 2011). But exclusion also happens in schools, with formal access to schooling not necessarily translated to epistemological access (Morrow, 2007). So, in this session, students are asked critically to consider South African schools and education in the light of the ways they reproduce, through various mechanisms, the inequities and injustices of South African society.

The second session within this proposition is used to give an international perspective on inclusive education. The belief that inclusive education will be conceived of, and practised differently in different countries and contexts, has given rise to a body of literature exploring inclusion in different contexts, and comparisons between or among countries. Against this tradition, students are asked what inclusive education means in the context of neo-liberalism and globalization. When inclusive education is merely seen as an issue of access to institutions within individual nations, we may be lured into thinking that each nation has equal capacity to address educational exclusion. Instead, students are asked to consider how a history of colonialism and underdevelopment in countries of the Global South compound the problems of educational exclusion. They are asked to consider how Education For All and the Millennium Development Goals relate to inclusive education; why comparisons of inclusive education across countries need to consider the historical and economic global context; and the extent to which issues of marginalization and exclusion in and from schools relate to global inequalities. These discussions are linked to international pressures (often felt through requirements set by the World Bank) that developing countries meet accountability targets and take part in standardised assessments, which have the potential to undermine more inclusive and socially just ways of educating (Liasidou and Symeou, 2016).

Inclusion and exclusion must be considered within specific contexts (Slee, 2000) and the South African context is obviously an important focal point for students. In global terms, South Africa comes relatively late to inclusive education, and takes into its inclusive education system the realities of past and present discrimination on the grounds of race and (dis)ability. The country seems to have adopted an incremental (some might say conservative) approach to inclusive education, with a very conciliatory attitude to separate special education. In the third session, I ask whether this is a betrayal of the ideals of inclusion, given Slee's $(2011,155)$ comment that, "The real and extensive suffering from which the demand for inclusive education is born does not afford a slow gestation for 
reform." Or, whether South Africa's approach is in fact realistic and inclusive, reminiscent of the political solution that ensured a relatively peaceful transition to democracy. It is apparent in the years since the publication of White Paper Six (Department of Education, 2001), that there are significant tensions and contradictions (Pather, 2011) in the ways in which inclusive education is understood and implemented in South Africa. Students are encouraged to engage with the source and result of these tensions and contradictions.

The final session conceptualised under this proposition asks what we gain by viewing inclusive education as an issue of social justice rather than special education. Guiding questions include: Are special education and social justice contradictory terms?, Can special education ever be socially just?, Is there specialist knowledge within special education that would be lost if inclusive education were to be uncoupled from special education? and How might the lens of special education limit, even distort how we view inclusive education? Students are required to read Artiles, Harris-Murri and Rostenberg's (2006) article which offers a summary of Dyson's influential distinction between different inclusion discourses, and also deals with different conceptions of social justice. This article suggests both possibilities and limitations of considering inclusive education in terms of social justice and offers opportunities for debate. Key issues that arise in this discussion relate to how social justice is conceptualised, and inevitably to a concern about learners being relocated from special to 'ordinary' classrooms in the name of inclusive education, but then finding themselves excluded from the epistemic goods of the school.

\section{Proposition two: Re-righting language}

This proposition is that, "Inclusive education recognizes language as an instrument of power and seeks to restore and embed a vocabulary of rights and justice in education" (Slee, 2011, 156). It is a proposition that urges a deconstruction of language to "isolate assumptions and intentions, to challenge authority, and open the possibility of counter intelligences" (p. 156). The tenets of critical literacy as espoused by Janks (2010) and Gee (2008) inform the three sessions in this section of the course.

The first session under this proposition asks students to use critical literacy to reveal the workings of power through language to exclude and marginalise. A critical literacy approach to a text (written, verbal or visual) requires students to raise critical questions like: In whose interests was this text produced?, What assumptions does the text producer make about the 
reader, and the subject?, Whose voices are silenced and whose voices are given prominence? and What constructed views of 'the way things are' are presented as natural? Students' task in this session is to explore how a critical approach to language can promote inclusive education, particularly by considering the role that critical literacy can play in "educating communities about exclusion" (Slee, 2011, 172). This work serves as a foundation for the second session which is concerned with issues of inclusion and exclusion in books and the media more generally, and in particular, how they fashion popular ideas about (dis)ability. In this regard, Slee $(2011,136)$ speaks of the "influence of media in producing particular pathologies of behaviour or medical identities". There are two distinct, but interrelated focal areas of this session. The first is to identify and resist negative and stereotypical portrayals of difference and disability in the media and literature, and to recognize the role of the media and literature in the construction of ableism, normalizing discourses and the pathologisation of disability. The second is to consider how literature can be harnessed by teachers in the pursuit of inclusion. This may be by using literature to promote an understanding of difference (or "sympathetic imagination", as Nussbaum $(1997,85)$ calls it), to foster critical literacy by enabling learners to identify the constructedness of an unequal world, or to teach social skills.

The third session invites students in this course to engage critically with textbooks in the field of special and inclusive education. Many of these textbooks are concerned with the processes of identifying learners who do not meet the standards of "normal", categorising them in terms of clusters of characteristics, assigning labels to the categories, and the learners themselves, and, based on these categories, designing and implementing educational interventions. This session is designed to enable students to think about these constructions of difference, as evidenced by their portrayal in textbooks. A key text is Brantlinger's (2006) chapter, 'The big glossies: How textbooks structure (special) education', supplemented by the critiques by Rice (2005) and Black-Hawkins (2012). Not only are students required to select a textbook from the library and write a critical review, they are also invited to explore ways in which their own views of learner difference and of inclusive education have been shaped by the textbooks they have encountered in their previous studies.

\section{Proposition three: Re-searching for inclusion}

The third proposition is that "Inclusive education employs a comprehensive array of research methodologies and tools in search of the complex structure and properties of exclusion and 
for ways to overcome its deleterious impacts" (Slee, 2011, 158). This proposition emphasises the need for a range of approaches that rise to the challenge of understanding the "complexity and dynamism of exclusion" (p.158) in ways that do not perpetuate oppression. For students preparing to do their research report in the field of inclusive education, this proposition is particularly important, and it often challenges students to reflect critically on what, with whom and how they research. The first session responding to this proposition asks students to consider how research in the field of inclusion and special education could work to perpetuate oppression and reinstate exclusion, and what researchers could/should do to resist this. This includes an interrogation of the role of the researcher's epistemology and his/her assumptions about difference and disability, and the place of special education (Barton and Clough,1995); an examination of how the position of the researcher is conceived - as a neutral and objective observer, or someone whose values, motivations and choices will determine the outcomes of research and so contribute to the construction of knowledge (Bines, 1995); and a consideration of who has the power in research relations and how this affects the construction, execution and results of the research process. Finally, the work of ideology in research is emphasised with specific reference to Brantlinger's (1997) seminal paper on “Using ideology” and Allan and Slee's (2008) book Doing inclusive education research.

The second session within this proposition turns to the possibilities and limitations of hearing the 'voices' of children and young people, something that has become something of a 'hot topic' in inclusive education research. Research in this tradition has seen researchers trying to understand how children and young people experience and understand inclusion and exclusion, with Slee (2011) noting that the perspectives of those who "are devalued and rendered marginal" (p.107) are needed. Students doing this course would read about various methodologies that have been used to listen to children and young people and engage with articles that document various configurations of participatory research (for example, Adderley, Hope, Hughes, Jones, Messiou, and Shaw (2015) and Messiou (2014)). While this type of research reveals insider perspectives and may be a lever for change, students are also asked to engage with critiques that question the epistemological value of such research. In this regard, they read Young (2000) who addresses concerns about voice research as not yielding powerful knowledge as it is individual and contingent, and not abstract. The third and final session in this proposition requires students to engage with the concepts of inclusive, emancipatory and transformative research. Each of these terms reflects resistance 
to the perpetuation of oppression in and through research, with each having nuances in the literature. Allan (2007) gives students an indication of what inclusive research might mean, the work of Barnes (2003) offers a lens on emancipatory disability research, and Mertens (2009) suggests what transformative research would entail. In exploring these concepts, students reflect on themselves as novice researchers, on the topics that they propose researching and on the methodologies that they plan to use.

\section{Proposition four: Re-visioning education}

In this final proposition, Slee offers inclusive education as “...An alternative vision for education as a democratic apprenticeship to build sustainable communities". In so doing, he firmly extricates inclusive education from its pre-occupation with the re-location of children with disabilities into 'regular' education. This final proposition is perhaps the most daunting in terms of the magnitude of the task that he proposes. The play on vision ("inclusion as an educational aspiration and strategy" (p.154)) and revision ("democratic schooling assumes educational reconstruction" (p.161)) in the proposition is apposite. It forces us to capture both the ideal of inclusive communities and the need for change in curriculum, policy, assessment and teacher education. This proposition is considered in the two final sessions of the course. In the penultimate session, students grapple with the question of how inclusive education could be regarded as an apprenticeship in democracy. This requires them to consider what is understood by "democratic education" and the extent to which democratic education and inclusive education are similar. Their readings take them first to Bernstein's (2000) introduction to Pedagogy, symbolic control and identity. Here, students' attention is drawn to Bernstein's explanation of the interrelated rights and distribution principles, and they are invited to answer the questions that he poses about the distribution of images. The students are then introduced various scholars whose work informs thinking about democratic education, including Gert Biesta, Iris Young and John Dewey. For many students who choose this course, this represents an unfamiliar 'language' (in the Bersteinian sense) in inclusive education, and they need structured support to access these ideas. Where the calendar allows for a thirteen week semester, this session is extended over two weeks. 
The final session of the course asks a broad question that challenges students to consider what it would it mean to reform education in South Africa as a truly inclusive enterprise. This question is prompted by Slee's $(2011,164)$ assertion that:

Reforming education is a manifold and complex task that reaches into the deep structures of education and schooling to produce different policies, practices and cultures.

By this point in the course, students have become aware of the extent and pervasiveness of educational exclusion, and have come to some understanding of how and why this exclusion is perpetuated. The readings for this session return to South African literature (such as du Toit and Forlin (2009) and Engelbrecht (2011)) to give students some sense of how scholars have tackled the issue. It is a turn to the interplay of the macro- and micro-politics of exclusion with the demand that we understand more about the problem of exclusion in schools, rather than suggesting naïve solutions - which may, perversely, perpetuate, rather than solve the problem. But it is also a realization that we have a responsibility to work towards making a material difference in the lives of learners who find themselves marginalized and excluded, and hence the need to seek real solutions for real learners in real schools.

\section{Re-viewing the course}

If the course demands that students ask critical questions of the scholarship they encounter and the research that they conduct, the course itself must be subject to re-view. This extends beyond course evaluations by students and colleagues (where it has been positively received), to considerations of its place in the academy, and in the South African context. There are many avenues this critique could take, including the commodification of inclusive education through its packaging as a postgraduate course, and the course's (over)reliance on Western texts in a context where decolonisation of the curriculum is a clarion call. But for my purposes here, and in response to Allan's call for inclusive teacher educators to find spaces where there is the "potential for political work" (2010), I suggest three responsibilities. First is an ongoing interrogation of the role of the teacher educator's “interests, concerns and projects" (Luckett, 2009, 451) in producing a pedagogic discourse of inclusive education. Second is finding ways to account for the recontextualisation process to the field at large and to those who are to acquire the knowledge. The third is acknowledging 
that all pedagogical choices made will have consequences, and taking responsibility for these consequences.

With respect to the masters course described in this article, I record two shifts that occur during the semester, and which shape the course in what Luckett $(2009,451)$ calls, "contextspecific and personal ways". The first is a shift over time from a focus on me (the teacher educator) and them (the students) to a focus on us and we (a community of "political individuals who must act" (Allan, 2010, 415)). The teacher educator has the initial responsibility to design a course that will enable students to position themselves to take part in the practices of the field and produce legitimate knowledge in the field. This imperative serves as an antidote to the danger of "descent into emotivism" that Allan $(2010,414)$ warns about. The course is designed for an imagined group of students, but is subsequently animated by an actual group of students, who bring their voices, stories and experiences to a class where dialogue, debate and discussion engender the "hope" that "the possibilities of change are not foreclosed" (Barton 2005 cited in Allan 2010, 415). This hope is reflected in the comment of a masters student who, at the end of the course, said,

We are now part of the inclusive activists' movement and so condemned and privileged to a life of alertness. We will share the difficulty, tension and struggle this creates, but also share in the new relationships it builds. (Coetzee 2012 cited in Walton 2016, 155).

\section{Conclusion}

Allan's (2010) call is for inclusive teacher educators to "reinvent themselves" by building civil society "through the enactment, rather than the promoting, of inclusive values" (p. 420). This is a challenge to teacher educators in terms of who they are and how they act with respect to their students and society at large. This article adds to the challenge by focusing on what teacher educators teach in pursuit of inclusive education, and argues for the opening of debate and discussion about pedagogising inclusive education knowledge in the academy. This, too, needs to be viewed as a political task, with teacher educators, as recontextualising agents producing a pedagogic discourse that furthers the "political project" (Slee, 2011, 70) inherent in inclusive education. 


\section{References}

Adderley, R. J., M. A. Hope, G.C. Hughes, L. Jones, K. Messiou, and P.A. Shaw. (2015). Exploring Inclusive Practices in Primary Schools: Focusing on Children's Voices. European Journal of Special Needs Education, 30(1): 106-121.

Allan, J. (2005). Inclusion as an ethical project. In: S. Tremain (Ed.). Foucault and the government of disability (281 -297). Michigan: University of Michigan Press.

Allan, J. (2007). Rethinking inclusive education. Dordrecht: Springer.

Allan, J. (2010). The Inclusive Teacher Educator: Spaces for Civic Engagement. Discourse: Studies in the Cultural Politics of Education, 31(4): 411-422.

Allan, J. and R. Slee. (2008). Doing inclusive education research. Rotterdam: Sense Publishers.

Apple, M., and L. Christian-Smith. (1991). The Politics of the Textbook. In M. Apple and L. Christian-Smith (Eds.), The politics of the textbook (1-21). New York: Routledge. Armstrong, D., A.C. Armstrong and I. Spandagou. (2011). Inclusion: By Choice or by Chance? International Journal of Inclusive Education, 15(1): 29-39.

Artiles, A. J., N. Harris-Murri and D. Rostenberg, D. (2006). Inclusion as Social Justice: Critical Notes on Discourses, Assumptions, and the Road Ahead. Theory into practice, 45(3): 260-268.

Barnes, C. (2003). What A Difference a Decade Makes: Reflections On Doing 'Emancipatory' Disability Research. Disability and Society, (18)1: 3 - 17.

Barton, L. and P. Clough. (1995). Conclusion: Many Urgent Voices. In P. Clough and L. Barton (Eds.), Making Difficulties: Research and The Construction of Special Educational Needs (143 - 147). London: Paul Chapman Publishing.

Bernstein, B. (2000). Pedagogy, Symbolic Control and Identity: Theory, Research and Critique (revised edition). Lanham: Rowman and Littlefield.

Bines, H. (1995). Risk, Routine and Reward: Confronting Personal and Social Constructs in Research On Special Educational Needs. In P. Clough and L. Barton (Eds.), Making Difficulties: Research and The Construction of Special Educational Needs (42 - 57). London: Paul Chapman Publishing.

Black-Hawkins, K. (2012). Developing Inclusive Classroom Practices: What Guidance Do Commercially Published Texts Offer Teachers? European Journal of Special Needs Education, 27(4): 499-516.

Brantlinger, E. (1997). Using Ideology: Cases of Nonrecognition of the Politics of Research and Practice in Special Education. Review of Educational Research, 67(4): 425-459. 
Brantlinger E. (2006). The Big Glossies: How Textbooks Structure (Special) Education. In E. Brantlinger (Ed.), Who Benefits from Special Education? Remediating (Fixing) Other People’s Children (45 - 76). Mahwah: Lawrence Erlbaum Associates Inc.

Coleman, L. (2012). Incorporating The Notion Of Recontextualisation In Academic Literacies Research: The Case Of A South African Vocational Web Design And Development Course. Higher Education Research and Development, 31(3): 325-338. doi:10.1080/07294360.2011.631519

Department of Basic Education. (2011). Action plan to 2014: Towards the Realisation of Schooling 2025. Pretoria: Government Printers.

Department of Education. (2001). Education White Paper Six: Special needs education. Pretoria: Government Printers

du Toit, P. and C. Forlin. (2009). Cultural Transformation for Inclusion, What Is Needed? A South African Perspective. School Psychology International 30(6): 644 - 655.

Engelbrecht, P. (2011). Equity in Inclusive Education in South Africa. In A. Artiles, E. Kozleski, and F. Waitoller (Eds). Inclusive Education. Equity Across Five Continents. (147-160). Cambridge, MA: Harvard Education Press.

Florian, L. (2012). Teacher Education for Inclusion: A Research Agenda For The Future. In C. Forlin (Ed.), Future Directions for Inclusive Teacher Education: An International Perspective (212-220). London: Routledge.

Gee, J.P. (2008). Social Linguistics and Literacies: Ideology in Discourses (3rd edition). Milton Park: Routledge.

Janks, H. (2010). Literacy and Power. New York: Routledge. Liasidou, A. and L. Symeou (2016). Neoliberal Versus Social Justice Reforms in Education Policy and Practice: Discourses, Politics and Disability Rights In Education, Critical Studies in Education, DOI: 10.1080/17508487.2016.1186102.

Loreman, T. (2013). Book Review: The Irregular School. Canadian Journal of Education, 36(1): 440.

Luckett, K. (2009). The Relationship Between Knowledge Structure And Curriculum: A Case Study In Sociology. Studies in Higher Education, 34(4): 441-453. doi:10.1080/03075070902772018

Mertens, D. (2009). Transformative Research and Evaluation. London: The Guilford Press. Messiou, K. (2014). Working with Students as Co-Researchers in Schools: A Matter of Inclusion. International Journal of Inclusive Education, 18(6): 601-613. doi: 10.1080/13603116.2013.802028. 
Morrow, W. (2007). Learning to Teach in South Africa. Pretoria: HSRC Press.

Pather, S. (2011). Evidence On Inclusion and Support for Learners with Disabilities In Mainstream Schools In South Africa: Off The Policy Radar? International Journal of Inclusive Education, 15(10), 1103-1117. doi: 10.1080/13603116.2011.555075

Nussbaum, M. (1997). Cultivating Humanity. A Classical Defense of Reform in Liberal Education. Cambridge, MA: Harvard University Press.

Republic of South Africa. (2015). Revised Minimum Requirements for Teacher Education Qualifications. Government Gazette No. 38487. Pretoria: Government printing Works.

Rice, N. (2005). Guardians of Tradition: Presentations of Inclusion in Three Introductory Special Education Textbooks. International Journal of Inclusive Education, 9(4), 405429. doi: 10.1080/13603110500147179

Rouse, M. (2010). Reforming Initial Teacher Education: A Necessary but Not Sufficient Condition For Developing Inclusive Practice. In C. Forlin (Ed.), Teacher Education for Inclusion (47-55). Abingdon, OX: Routledge.

Shalem, Y. and L. Slonimsky. (2010). The Concept of Teaching. In Y. Shalem and S. Pendlebury (Eds.). Retrieving teaching (12 - 23). Cape Town: Juta.

Sharma, U., C. Forlin and T. Loreman. (2008). Impact of Training On Pre-Service Teachers' Attitudes And Concerns About Inclusive Education And Sentiments About Persons With Disabilities. Disability and Society, 23(7): 773-785. doi:

$10.1080 / 09687590802469271$

Singh, P. (2002). Pedagogising Knowledge: Bernstein's Theory of the Pedagogic Device. British Journal of Sociology of Education, 23(4): 571 - 582.

Slee, R. (2000). Professional Partnerships For Inclusive Education? Melbourne Studies in Education, 41(1), 1-15, DOI: 10.1080/17508480009556341.

Slee, R. (2011). The Irregular School. Milton Park: Routledge.

Walton, E. (2016). The Language of Inclusive Education. Milton Park: Routledge.

Walton, E. (2017). Inclusive education in initial teacher education in South Africa: Practical or professional knowledge? Journal of Education, 67: 101 - 128.

Walton, E. and L. Rusznyak (2017). Choices in the design of inclusive education courses for pre-service teachers: The case of a South African university. The International Journal of Disability, Development and Education, 64(3): 231-248. 
Waitoller, F. and A. Artiles (2013). A Decade of Professional Development Research for Inclusive Education: A Critical Review and Notes for A Research Program. Review of Educational Research, 83(3): 319-356.

Yates, L. (2012). The Irregular School: Exclusion, Schooling and Inclusive Education. Journal of Education Policy, 27(3), 441-442. doi:10.1080/02680939.2011.642652

Young, M. F. D. (2000). Rescuing The Sociology of Educational Knowledge from the Extremes of Voice Discourse: Towards A New Theoretical Basis for The Sociology of the Curriculum. British Journal of Sociology of Education, 21(4): 523-536. 